\title{
Urban Network in Strategic Areas in Indonesia Case Study: Sambas Regency, West Kalimantan
}

\author{
Syaiful Muazir ${ }^{1}$ and Horng- Chang Hsieh ${ }^{2}$ \\ ${ }^{l}$ Department of Architecture, Tanjungpura University, Pontianak-Indonesia \\ ${ }^{2}$ Department of Urban Planning, National Cheng Kung University, Tainan-Taiwan \\ syaifulmuazir@teknik.untan.ac.id ${ }^{1 *}$ and hchsieh@mail.ncku.edu.tw
}

Received: 29 August 2018 Final Version Received: 28 August 2019

\begin{abstract}
Indonesia has endorsed a spatial planning law and identified "strategic areas" to promote development in lagging regions. One such regency (region) that has strategic value is Sambas. Sambas regency has two types of "strategic areas", namely border areas and tourism strategic areas. This paper is a case study on the Sambas regency in West Kalimantan. The study was undertaken at Paloh district (representative of border areas), and Sambas district (representative of tourism areas, besides being the capital city of Sambas regency). This paper attempts to explore and examine one of the "urban network" types, which is a technical/infrastructure network, to assess the orientation tendency within the network concept. It examines some network measurements to explore the area's position by using degree/density, closeness, centrality, cluster, and structural equivalence. The findings indicate that most of the infrastructure network in Sambas regency is still centralized and oriented towards Sambas district and some easy access areas, in line with its being the province's capital city (southern part). Regarding the border area (Paloh), overall the linked networks are still limited due to the development priorities and considering the available access and distance problem. To boost development in the border area, interaction should be enhanced, by considering the role of each area and strengthening their connection through modifying the network.
\end{abstract}

Keywords: Urban Network, Strategic Areas, Sambas, Indonesia

\section{INTRODUCTION}

As one of the world's largest and most populous countries, Indonesia's development has become a major challenge for the government. As regards spatial planning, the direction of development in Indonesia is guided by Law No. 26 of 2007 related to spatial planning, the details of which have been vertically and hierarchically arranged by the government regulations. When implemented, spatial planning in Indonesia will consist of two plans: (1) general plan, and (2) detailed plan. The general plan hierarchically consists of a national spatial plan, provincial spatial planning, and a regency/city spatial plan. The detailed plan hierarchy consists of (1) Island and national strategic areas, (2) provincial strategic areas, (3) regency/city detailed spatial plan and strategic areas. Regarding the development of "special cases", the "special areas" or "strategic areas" classification has been introduced to encourage development in such areas. A (national) strategic area is an area that takes priority for spatial arrangement in consideration of its significant influence on the nation's sovereignty, defense and state security, economics, society, culture, and environment, including areas that have been identified as world heritage sites. Under the national strategic area, provincial, regency, and city strategic areas are set based on the priority of spatial arrangement, given their importance from the economic, social, cultural, and environmental aspects. One such "strategic region" in West Kalimantan Province is Sambas regency. Sambas regency has two "national strategic activity centers" (border areas) located in Paloh (Temajuk) and Sajingan Besar (Aruk) districts, which are adjacent to Sarawak, Malaysia. Besides, under the National Tourism Master Plan, Sambas regency has also been designated as one of the "national tourism strategic areas", distributed over several districts of Sambas regency, and one of them is located in Sambas district, which is the capital city of Sambas regency. Sambas regency was assigned the status of a "strategic region" because of its location near the neighboring country (border 
area) as well as the condition of several of its districts, which are included in the "lagging areas".

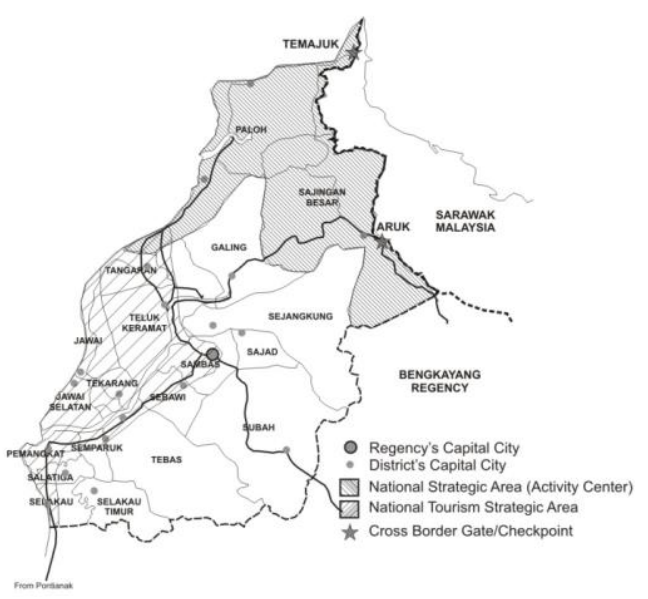

Figure 1- Strategic Areas in Sambas Regency, West Kalimantan

Source: Modified from Sambas's Spatial Plan, 2012

Under the development agenda, the primary purpose of regional development planning is deciding on the general distribution of new activities and development (Glasson \& Marshall, 2007). Regions should be connected to each other to be able to interact with each other and share the flow of goods and services. Through connectivity, connections between people, goods, and regions are encouraged, and more and more connections are produced (Staeheli, 2012). Regarding the measurement of connectivity, it has a close relationship with the network concept. The application of network analysis to a city or region is based on the adaptation of social network analysis. It has been further developed in other disciplines, including urban studies, where urban professionals have begun to conceive the city analytically rather than holistically by disaggregating it into a series of systems. In the contemporary version of this 'perspective', the city has been turned into a network: the urban network. Therefore, the city can be imagined as a series of networks that influence each other, not being limited by administrative boundaries or zoning. Urban studies continue to evolve this concept towards an interconnected city system.

Regarding Sambas regency as a border area, some constraints still persist in the border areas due to the lack of attention in the past. These problems include (1) low educational level among most of the population (2), poor access to health services, (3) unbalanced population distribution/density, (4) simple agriculture technology, and (5) limited facilities and infrastructure. However, given the current spirit of reform and regional autonomy, the central government through state laws and regulations has been paying special attention to the border areas through the establishment of strategic areas, both in the urban system (in spatial structure) as well as national strategic areas (in spatial pattern).

This paper is a case study of a "strategic region" in Indonesia, the Sambas regency. The study was undertaken in two strategic areas of Sambas regency, which are Paloh district (representative of border areas), and Sambas district (representative of tourism areas, besides being the capital city of Sambas regency). The aim of this paper is to examine one of the "Urban Network" types; which is the "technical" or infrastructure network in this strategic region (Sambas regency). Subsequently, it discusses the tendency of orientation of the "technical" urban network within the strategic areas, which can provide insight into the interaction between areas.

\section{FRAMEWORK OF ANALYSIS}

\subsection{Networks Coming to Urban Studies}

Network analysis is not a discipline confined to only one branch of academia or industry (Phillips \& Diaz, 1981). Furthermore, the authors mention, the real strength of network analysis lies in the fact that it can successfully be applied to almost any problem to construct a proper network representation. Described as a "metaphor", sometimes network comes in and goes out of sociological fashion and is often employed in some "incompatible ways" (Erickson, 2012); the use of metaphors in network is probably inevitable and enhances the understanding of social experience. Heydebrand (1999) mentioned that there would be many distinct perceptions and many stories about the particular ties and interconnection of ties. Furthermore, offering more understanding about the network metaphor, according to him there are three different types of network, these being (1) technical network (e.g., telephone, internet), (2) transactional networks (e.g., transportation, trade), and (3) social and socio-technical networks. Technical networks can be like the telephone, the automobile, or the computer.

Drewe (as cited in Albrechts \& Mandelbaum, 2005) has argued that today's architects and 
urban designers have neglected the vast flows of the networked world and the paradigmatic challenge of the concept of networks developed by other innovators, when dealing with spatial planning. They are still influenced by zonal thinking and have not seen the infrastructure of cities as being within their domain. Furthermore, Drewe adopted Dupuy's "levels of network" in terms of diagrammatic exposition of network level within the city/urbanism. Dupuy distinguished three interacting levels of operators that (re)organize an urban space. Level 1 involves the suppliers of technical networks: water, energy, transport, and telecommunication. Level 2 is known as the functional network of common interest users, such as production, distribution, consumption, and social contacts. Level 3 consists of those users of functional networks who make actual, selective use of technical networks and services for their special purposes: households or companies, creating their own virtual city.

Combining network as "metaphor" and network operators from the description above, there are three tiers of urban network types. In common understanding, a technical network leads to an infrastructure network, seeing its nature of supporting basic physical needs. In short, adapting Neuman (2006), the types of infrastructure are divided into: (1) utilities (gas, electricity), (2) public works (highways, bridges), (3) community facilities (schools, parks), (4) telecommunications (telephone, internet), (5) transportation (roads, sidewalks), and (6) knowledge networks (universities, research institutes). From another perspective, infrastructure inside the spatial plan (in Indonesia) is divided into road, public transportation (land, sea, and air), energy (electricity), telecommunication, water sources, and environment management (water and waste).

\subsection{Network Approach}

Generally, the network concept is based on a relationship between entities such as organizations or people (Scott et al., 2008). The network properties studied by researchers relate to the structure of these relationships. According to Knoke and Yang (2008), the underlying assumption of a network is the perspective emphasizing structural relations, whereas Scott (2013) said that it is about relationships. Borgatti, Everett, and Johnson (2013) in their book "Analyzing Social Networks" provide (at least) three types of "basic" network analyses that can be used to perform network measurement, which are (1) centrality, (2) subgraph, (3) and equivalence. Centrality is about the "most important" actors in a social network (Wasserman \& Faust, 1994). They go on to say that the most important or the most prominent actors are usually placed in strategic locations within the network.

The four basic centrality measures are: (1) degree, (2) closeness, (3) betweenness, and (4) eigenvector. The second approach is subgroup; subgroup is a group of actors who interact with each other to such an extent that they could be considered a separate entity or a cohesive subgroup (Borgatti et al., 2013). According to Wasserman and Faust (1994), cohesive subgroups are subsets of actors among whom there are relatively strong, direct, intense, frequent, or positive ties, and can be explored through "clique". The last approach in network analysis is structural equivalence. According to Borgatti et al. (2013), structural equivalence is a form of direct connection of an actor to other actors in the network. It is based upon identifying similar positions and seeks clusters of nodes that are connected to each other. The authors illustrate how two actors/nodes are structurally equivalent if they send ties to the same third parties, and receive ties from the same third parties. The two actors do not need to have a direct tie. Wasserman and Faust (1994) concluded that two actors are structurally equivalent if they have identical ties to and from all other actors in the network. Structural equivalence can be calculated using blockmodels.

Another "structural" measurement mode is structural holes. The concept of structural holes leads naturally to the hypothesis that actors, who have many structural holes (buffer or space; no tie between actors) in their own network have an incentive to work as brokers in between, and expect some profit from doing so (Swedberg, 1994; Hanneman \& Riddle, 2005). Structural holes are the gaps between non-redundant contacts. Because of the hole between them, the two contacts provide network benefits to the area, which in some degree are additive rather than overlapping (Burt, 1992). Burt postulates further that the structural holes connecting nonredundant contacts function as a buffer. Contacts are redundant to the extent that they lead to the same people, and so provide the same information benefits. Hanneman and Riddle (2005) add that structural holes express the positional advantage or disadvantage of individuals, which results from how they are embedded in a neighbourhood. 
Table 1 -Mathematical Expression in Network Analysis

\begin{tabular}{|c|c|c|c|c|}
\hline No & $\begin{array}{c}\text { Analysis } \\
\text { Tools }\end{array}$ & Definition & Mathematical Expression & Source \\
\hline 1 & Degree (in/out) & $\begin{array}{l}\text { Number of lines that are incident } \\
\text { with it; number of ties of a given type } \\
\text { that a node has }\end{array}$ & $k_{i}^{\text {out }}$ & $\begin{array}{l}\text { Scott, Baggio, } \\
\& \text { Cooper, } \\
2008 \text {; Borgatti, } \\
\text { Everett, \& } \\
\text { Johnson, } 2013\end{array}$ \\
\hline 2 & Closeness & $\begin{array}{l}\text { It reflects how close the actors are to } \\
\text { reach other, which means that an } \\
\text { actor is central if it quickly interacts } \\
\text { with all others }\end{array}$ & $\left.\left.i_{i,} n_{j}\right)\right]^{-1}$ & $\begin{array}{l}\text { Wasserman \& } \\
\text { Faust, } 1994\end{array}$ \\
\hline 3 & Betweenness & $\begin{array}{l}\text { The one in the middle, the one } \\
\text { between the others, and become a } \\
\text { "bridge" between others; The } \\
\text { controller of the flow. }\end{array}$ & $g_{j k}$ & $\begin{array}{l}\text { Wasserman \& } \\
\text { Faust, 1994; } \\
\text { Borgatti, } \\
\text { Everett, \& } \\
\text { Johnson, 2013 } \\
\end{array}$ \\
\hline 4 & Eigenvector & $\begin{array}{l}\text { An effort to find the most central } \\
\text { actors in terms of the overall network } \\
\text { structure; A measure of "popularity" } \\
\text { that a node is connected to nodes that } \\
\text { are themselves well connected. }\end{array}$ & & $\begin{array}{l}\text { Hanneman \& } \\
\text { Riddle, 2005; } \\
\text { Borgatti, } \\
\text { Everett, \& } \\
\text { Johnson, 2013; } \\
\text { Borgatti, 1995 } \\
\end{array}$ \\
\hline 5 & Clique & $\begin{array}{l}\text { Groups or actor who interact with } \\
\text { each other to such an extent that they } \\
\text { could be a group of close } \\
\text { relationship, with a minimum of } 3 \text { as } \\
\text { the number of the smallest group }\end{array}$ & & $\begin{array}{l}\text { Borgatti, } \\
\text { Everett, \& } \\
\text { Johnson, 2013; } \\
\text { Wasserman } \\
\text { and Faust, } \\
1994\end{array}$ \\
\hline \multirow{3}{*}{6} & \multirow{3}{*}{$\begin{array}{l}\text { Structural } \\
\text { Equivalence: } \\
\text { Blockmodels } \\
\text { (CONCOR) }\end{array}$} & \multirow{3}{*}{$\begin{array}{l}\text { Partitioning the vertices of graph into } \\
\text { similarity classes (block) }\end{array}$} & \multirow[t]{3}{*}{$\begin{array}{l}\text { Repeated calculation of correlations } \\
\text { between rows (or columns) and all rows (or } \\
\text { columns) until the values }+1 \text { or }-1 \text { so it can } \\
\text { be portioned (blocked) }\end{array}$} & \multirow{3}{*}{$\begin{array}{l}\text { Wasserman } \\
\text { and Faust, } \\
\text { 1994; }\end{array}$} \\
\hline & & & & \\
\hline & & & & \\
\hline 7 & Structural Holes & $\begin{array}{l}\text { It is relationship of non-redundancy } \\
\text { between two contacts; Space } \\
\text { between connected people, "buffer" } \\
\text { between other members; As the } \\
\text { result of the hole, the two contacts } \\
\text { provide network benefits. }\end{array}$ & $q$ & $\begin{array}{l}\text { Burt, 1992; } \\
\text { Hanneman \& } \\
\text { Riddle, } 2005\end{array}$ \\
\hline
\end{tabular}

Source: Muazir, 2016

\section{METHODOLOGY}

The focus of this research specifically is the study of "technical" or infrastructure networks as part of urban networks in a strategic region of Indonesia. This research used Sambas regency in West Kalimantan province as a study site for the case study. Several types of infrastructure were used, including roads, public transportation, water supply, energy (electricity), waste management, and telecommunication. Data collection was performed in several ways, such as interviewing the available infrastructure operators, searching documents (technical documents), and observation. To classify data types and develop them into a research guide (e.g., interview guide, questionnaire questions, etc.), it is first necessary to identify what the network is about. As suggested by three basic studies on the subject (Knoke \& Yang, 2008; Scott, 2013; and Borgatti et al., 2013), data collection in network analysis always comprises (1) connection/connectivity, and relation/relationship. Borgatti et al. (2013) point out that network theorizing is based on a view of ties as conduits through which things flow. From the three types of network data (connection, relation, and flow), each required 
information/data was adjusted with the urban types that were explored and analyzed (technical/infrastructure). The indicators of required information/data to explore the urban (network) types were referenced and interpreted based on the network data required in the network analysis.

Table 2 - Network Data/ Required Data

\begin{tabular}{lll}
\hline No & Network Data & \multicolumn{1}{c}{ Required Data } \\
\hline \multirow{4}{*}{ Connection } & 1. Origin location - destination \\
& 2. Distance/length and connection \\
& 3. Direction \\
& 4. Point to point connection \\
& 5. Place and access \\
& 6. Movement and distribution \\
& 7. Connection between \\
\hline \multirow{4}{*}{ Relationship } & 1. Joint of action, sharing, links of partner/parties \\
& 2. Type of interaction \\
& 3. Profit/sharing/exchange \\
& 4. Cooperation /alliance \\
& 5. Mutual benefit \\
\hline \multirow{4}{*}{ Flow } & 1. Edge of connection/network \\
& 2. Outgoing - ingoing \\
& 3. Origin - destination \\
& 4. Expansion \\
& 5. Spread \\
& 6. Nodes and arc interaction \\
\hline
\end{tabular}

Source: Muazir, 2016

Table 3- Research Variable and Required Data

\begin{tabular}{|c|c|c|c|c|}
\hline No & $\begin{array}{c}\text { Factor } \\
\text { (Variable) }\end{array}$ & Level & Network Data & Required Data \\
\hline 1 & $\begin{array}{l}\text { Technical } \\
\text { network: } \\
\text { infrastructure }\end{array}$ & $\begin{array}{l}\text { 1. Roads } \\
\text { 2. Public transport } \\
\text { 3. Energy } \\
\text { 4. Telecommunication } \\
\text { 5. Water Supply } \\
\text { 6. Waste management }\end{array}$ & $\begin{array}{l}\text { 1. Distance/length } \\
\text { 2. Direction } \\
\text { 3. Point to point } \\
\text { connection/ } \\
\text { origin - } \\
\text { destination } \\
\text { 4. Place and } \\
\text { 5. access } \\
\text { 6. Connection } \\
\text { between }\end{array}$ & $\begin{array}{l}\text { 1. Segment and connection } \\
\text { 2. Location and routes } \\
\text { 3. Location and routes } \\
\text { 4. Location and routes } \\
\text { 5. Source, piping, and service } \\
\text { area } \\
\text { 6. Source, grid, and service } \\
\text { area } \\
\text { 7. Processing unit and } \\
\text { coverage } \\
\text { 8. Service area, connection, } \\
\text { and distribution }\end{array}$ \\
\hline
\end{tabular}

Source: Muazir, 2016

A network analysis technique was adopted to analyze the technical network or infrastructure (e.g., degree, closeness, centrality, sub-graph, and structure/block). Calculation and illustration were supported by UCINET software (Borgatti, Everett, \& Freeman, 2002). Following translation of the data (numeric to the narrative) the result was discussed and overlaid for each network to obtain a comprehensive picture of the trends in the "technical" urban networks" orientation and condition.

\section{RESULT AND DISCUSSION}

\subsection{Infrastructure Network}

According to the mid-term development plan in Sambas regency, infrastructure includes roads, water supply, terminals, ports, airports, canals and dams, embankments, sewage, trash, electricity, and telecommunication. The discussion about infrastructure network in this part focuses on the measurement of network 
elements such as degree and centrality, proximity or closeness, sub-graph, and finally constructing an equivalent structure (blockmodels and holes) that can provide information about the position and role of areas/locations inside the whole existing network. The types of infrastructure to be used include (1) roads, (2) ports, (3) airports, (4) railways, (5) water supply, (6) energy (electricity), (7) waste management, and (8) telecommunication.

\subsection{Road}

The road network in Sambas regency is 696,633 $\mathrm{km}$ in length (in 2013). Furthermore, the management and control of roads are divided into several levels of responsibility, such as national, provincial, regency, village, and national strategic. Most of the responsibility is at the village and regency level (38\% and 39\% respectively), while the remainder are national strategic, national, or provincial roads. As a strategic area (designated as national strategic activity center), the road status in the border districts of Sambas regency (Paloh and Sajingan Besar) is mostly included under national strategic (e.g., Sambas-Temajuk), whose funding can be supported by several levels of government (national, province, regency), particularly the central government. However, as recorded in 2013, as much as $49 \%$ of the roads were still categorized as being in damaged condition.

\subsection{Public Transportation}

In terms of public (land) transportation, traffic land management in Sambas regency is arranged in a set of routes and collected into a unit of a transportation network. This transportation network is assigned based on regency regulations, which includes point of origin, final destination, and the track (route) in between according to the road class. The transportation network in Sambas regency consists of (1) intervillage network, (2) inter-city network, and (3) border network. According to the strategic plan (2012-2016) of the Department of Transportation, Communication, and Information, there are 39 inter-village routes, 12 inter-city routes, and 2 border routes that connect areas in Sambas regency. According to the Department of Transportation, Communication, and Information, there is 1 main port and 19 main piers are distributed across Sambas regency. For operation, there are 2 ports/piers as the main collector ports, located in Sentete and Merbau. Regarding their current condition, in fact the number of boats (water transportation) as well as their frequency and passenger flow have tended to decrease. So far, there is no active airport in Sambas regency. The international or major airport is still located in Pontianak city, as the province's capital city. Besides, other airports are mostly located in the east and south of West Kalimantan, such as Sintang, Kapuas Hulu, and Ketapang regency. However, Sambas's spatial plan and other vertical plans have projected the opening of an airport in Paloh district that will function as a "collector" airport on the scale of tertiary services. There is no railway track in Sambas, until date. However, the medium-term development plans as well as the spatial plan of Sambas regency include a proposal to lay railway tracks linking the provincial capital to Sambas regency and also for connecting to other regencies/cities. As regards the direction of the spatial plan, the railway tracks will be laid connecting two corridors: corridor (1) Aruk - Sambas - Pemangkat Singkawang, and corridor (2) Sambas Bengkayang.

\subsection{Water Supply}

Generally speaking, clean water management in Sambas regency is organized by the local water company "Muare Ulakan". Of the 19 districts in Sambas, the water company is only able to serve six districts (unit of services), which are (1) Sambas, (2) Tebas, (3) Semparuk, (4) Pemangkat, (5) Selakau, and (6) Teluk Keramat. The local water company uses four water sources: Sambas River, Pedade River, Sebedang Lake, Semelagi Hulu, and the Mountain spring in Selindung. In general, the operations of the water company's services are centralized in Sambas district; each unit of service in the accessed district has its own water installation and uses fresh-water resources from the existing potential/nearest locations. Most of the local distribution is by the road grid. The service only covers $26 \%$ of the total service areas and is mostly located in the eastern part of Sambas.

\subsection{Electricity}

At the provincial level, the State Electricity Company (PLN) in West Kalimantan has developed a centralized electricity system (khatulistiwa system). However, the system only serves some regencies/cities situated in Pontianak, Kubu Raya, Mempawah, Bengkayang, Singkawang, and Sambas through four power plants located in Sei Raya, Siantan, and Singkawang. For other regencies/cities outside the system, they still use individual 
power plants located in each regency/city. Electricity service in Sambas regency is divided into three areas of service (Rayon): Pemangkat service area, Sambas, and Sekura. These three service areas have their main operational hub in Singkawang city. There is a power plant (diesel) in Sambas district, but after connection to the main system (khatulistiwa system), the power plant in Sambas serves as the main relay station, which receives transmission directly from Pontianak city. In Sambas, the electricity system serves almost all areas (districts); only Temajuk in Paloh district has its own (diesel) power plant,while Sajingan Besar district purchases power from Sarawak, Malaysia.

\subsection{Waste Management}

The waste (garbage) management system in Sambas regency is still handled entirely by the regency governments through the Department of Public Works. Waste transportation is still highly dependent on local governments. The current situation has started to cause problems, because while the volume of waste has been increasing the transportation tools (dump trucks) have decreased. Besides, the landfill is also too far from the area of service. At the waste landfill, there has been a lack of waste reduction activities, whether through recycling efforts or waste segregation. Waste management in the final waste landfill is still confined to open dumping. In daily life, people carry out the reduction of waste by burning it on their land. Waste management services in Sambas regency have so far not covered all the districts. Some districts which enjoy waste management services are: (1) Sambas, (2) Tebas, (3) Semparuk, (4) Pemangkat, (5) Salatiga, (6) Selakau, (7) Teluk Keramat, (8) Jawai, and (9) Jawai Selatan. Waste handling in Sambas starts from households that collect their waste or garbage, which is then taken to a temporary dumpster, which serves as a collector for the garbage that comes from the households. Garbage in the temporary dumpster is then transported to the final processing area or landfills.

\subsection{Telecommunication}

For fixed line services, the Telkom (company) based in Pontianak city provides the telecommunication network. The Telkom office in Pontianak serves as the main office (Regional Office of Telecommunication). Under the Pontianak office, there are Telecommunication Areas in Singkawang, Sanggau, Sintang, and Mempawah. For Sambas regency, the services are operated under Singkawang Telecommunication Area which has several branches (Telecommunication Branches) such as (1) Singkawang city itself, (2) Pemangkat, (3) Tebas, (4) Sambas, and (5) Bengkayang. The telecommunication branch area in Sambas focuses on marketing and transmitting telecommunication signals to other districts in Sambas, while other administrative and special technical aspects are operated from Singkawang.

Table 4 - Technical/Infrastructure Network in Sambas Regency

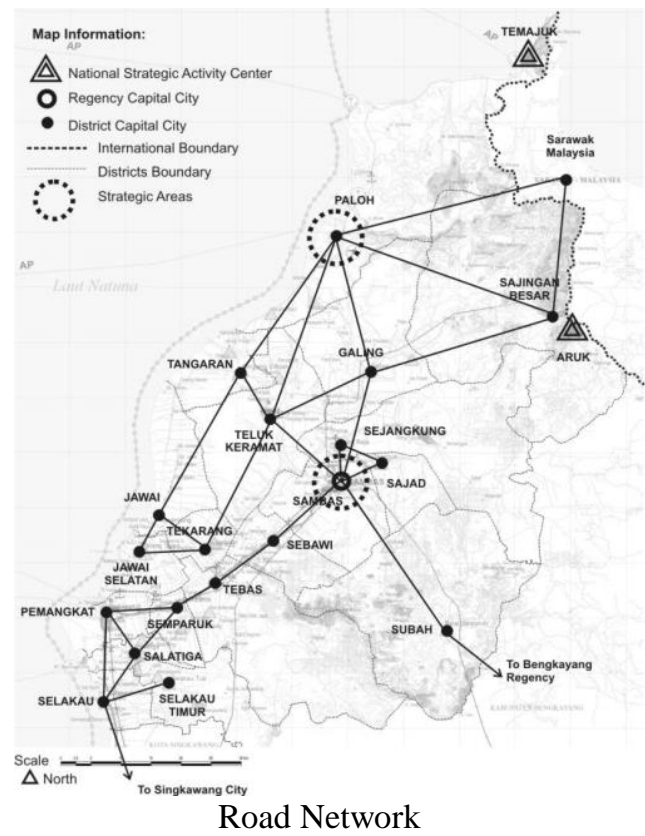

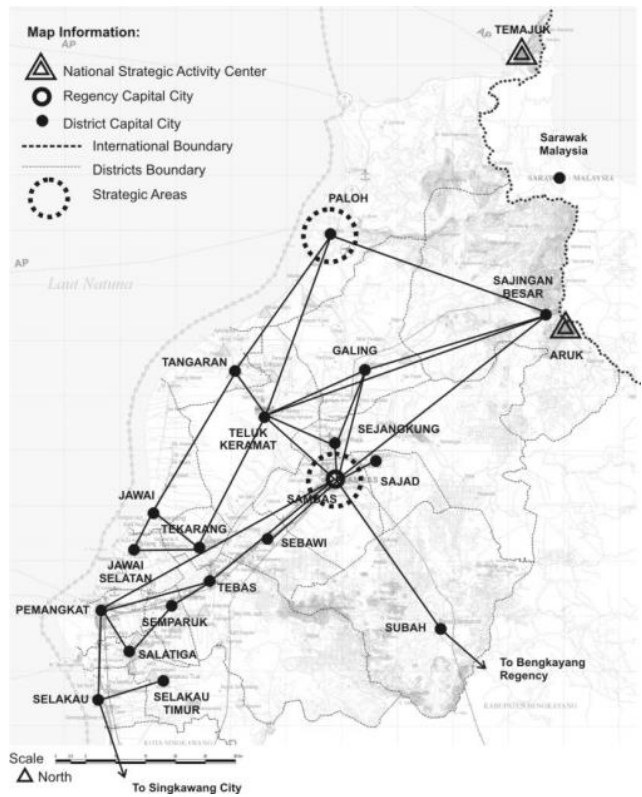

Public Land Transportation Network 


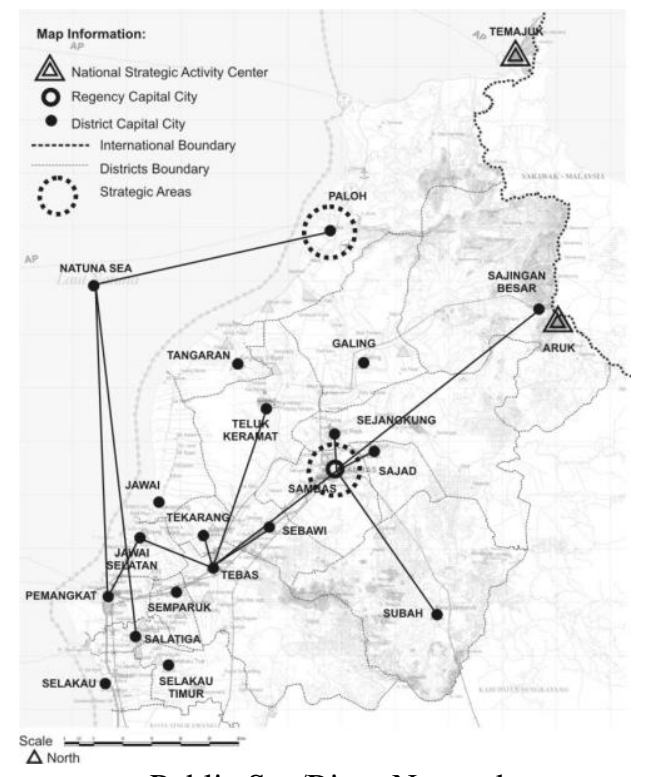

Public Sea/River Network
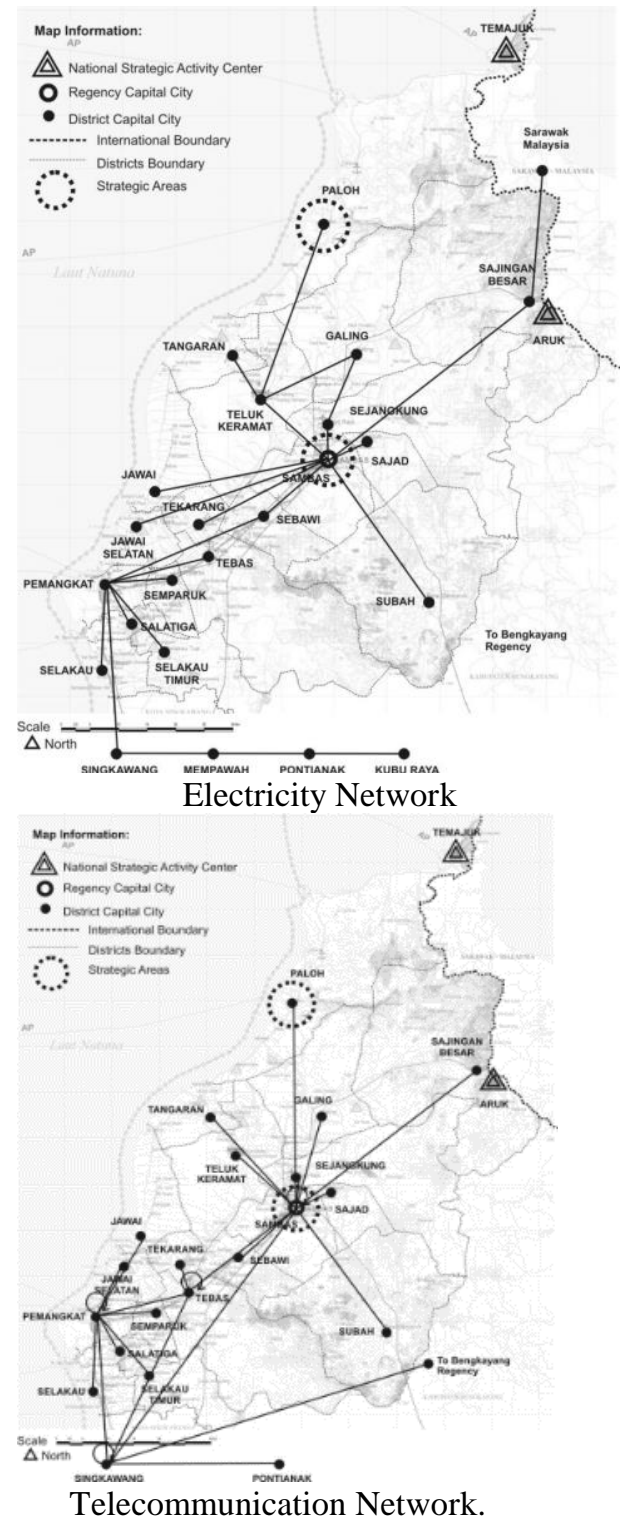

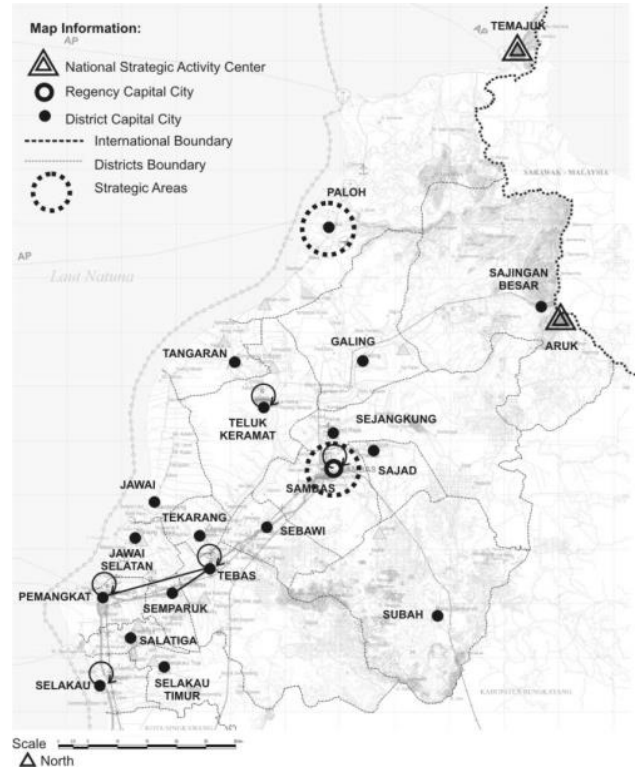

$\triangle$ Worth $\quad$ Water Supply Network

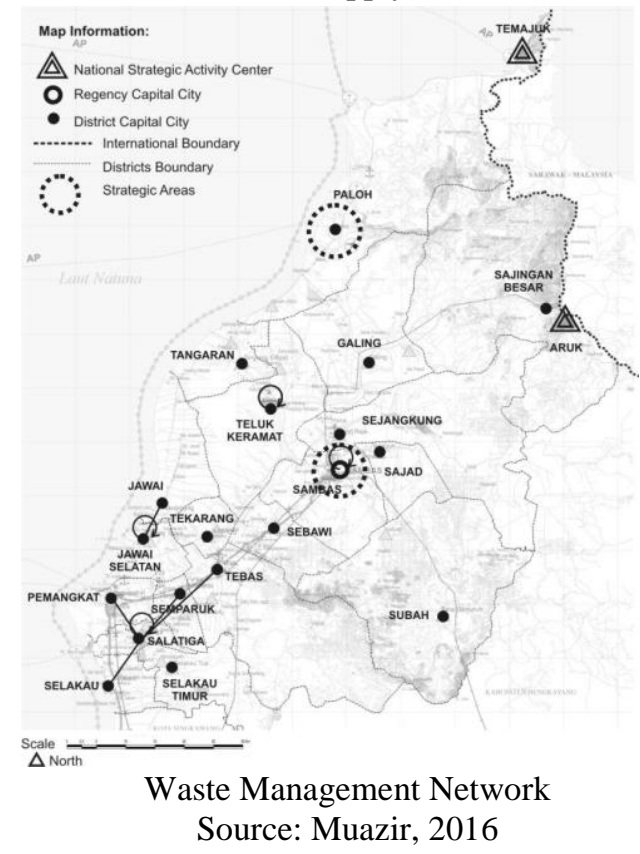

\subsection{Network Measurement}

This part focuses on the measurement of network elements such as degree and centrality, proximity or closeness, centrality, sub-graph, and finally constructs an equivalent structure (blockmodels and holes) that can provide information about the position and role of areas/locations within the entire existing network. The types of infrastructure to be used are those which have the connection or networks, such as (1) roads, (2) ports, (3) airports, (4) railways, (5) water supply, (6) energy (electricity), (7) waste management, and (8) telecommunicatio 
Table 5. Network Measurement

\begin{tabular}{|c|c|c|c|c|c|c|c|c|c|c|c|c|c|c|c|c|c|c|c|c|c|c|c|c|c|c|c|c|}
\hline \multirow{2}{*}{ CODE } & \multirow{2}{*}{ DISTRICT } & \multicolumn{9}{|c|}{ Road } & \multicolumn{9}{|c|}{ Public Land Transportation } & \multicolumn{9}{|c|}{ Public Sea/River Transportation } \\
\hline & & 1 & 2 & 3 & 4 & 5 & 6 & 7 & 8 & 9 & 1 & 2 & 3 & 4 & 5 & 6 & 7 & 8 & 9 & 1 & 2 & 3 & 4 & 5 & 6 & 7 & 8 & 9 \\
\hline $\mathbf{A}$ & Selakau & 4 & 4 & 107 & 19. & 18. & 0 & 1 & 3.5 & 0.8 & 2 & 1 & 58 & 34. & 19. & 7. & 0 & 3 & 1 & & & & & & & & & \\
\hline $\mathbf{B}$ & Selakau Timur & 1 & 1 & 127 & 16. & 0 & 0. & 0 & 1 & 1 & 0 & 1 & 77 & 25. & 0 & 1. & 0 & 1 & 1 & & & & & & & & & \\
\hline $\mathbf{C}$ & Pemangkat & 3 & 3 & 92 & 22. & 12. & 0. & 2 & 1.6 & 0.5 & 4 & 2 & 43 & 46. & 38. & 28. & 2 & 3.8 & 0.7 & 2 & 0 & 36 & 36. & 38. & 18. & 0 & 2 & 1 \\
\hline D & Semparuk & 3 & 3 & 79 & 26. & 38. & 1. & 0.4 & 2.3 & 0.7 & 3 & 1 & 60 & 33. & 0. & 14. & 2 & 1.7 & 0.5 & & & & & & & & & \\
\hline $\mathbf{E}$ & Salatiga & 3 & 3 & 92 & 22. & 12. & 0. & 2 & 1.6 & 0.5 & 0 & 2 & 61 & 32. & 0 & 9. & 0.4 & 1 & 0.5 & 1 & 0 & 56 & 23. & 0 & 3. & 0 & 1 & 1 \\
\hline $\mathbf{F}$ & Tebas & 2 & 2 & 69 & 30. & 42. & 4. & 0 & 2 & 1 & 0 & 3 & 47 & 42. & 3. & 25. & 1.3 & 1.8 & 0.6 & 1 & 4 & 26 & 50 & 74. & 78. & 0 & 5 & 1 \\
\hline $\mathbf{G}$ & Tekarang & 3 & 3 & 77 & 27. & 11. & 26. & 1 & 2.3 & 0.7 & 3 & 0 & 56 & 35. & 12. & 18. & 1 & 2.3 & 0.7 & 0 & 1 & 38 & 34. & 0 & 30. & 0 & 1 & 1 \\
\hline $\mathbf{H}$ & Sambas & 6 & 6 & 55 & 38. & 68. & 50. & 1 & 5.3 & 0.8 & 9 & 0 & 35 & 57. & 69. & 68. & 2 & 7.7 & 0.8 & 1 & 4 & 30 & 43. & 53. & 75. & 0 & 5 & 1 \\
\hline I & Subah & 2 & 2 & 73 & 28. & 9. & 14. & 0 & 2 & 1 & 1 & 1 & 52 & 38. & 10 & 16. & 0 & 2 & 1 & 1 & 0 & 42 & 30. & 0 & 29. & 0 & 1 & 1 \\
\hline $\mathbf{J}$ & Sebawi & 2 & 2 & 61 & 34. & 46. & 14. & 0 & 2 & 1 & 0 & 1 & 54 & 37. & 0 & 15. & 0 & 1 & 1 & 1 & 0 & 38 & 34. & 0 & 30. & 0 & 1 & 1 \\
\hline $\mathbf{K}$ & Sajad & 2 & 2 & 74 & 28. & 0 & 18. & 1 & 1 & 0.5 & 0 & 1 & 54 & 37. & 0 & 15. & 0 & 1 & 1 & 1 & 0 & 42 & 30. & 0 & 29. & 0 & 1 & 1 \\
\hline $\mathbf{L}$ & Jawai & 3 & 3 & 91 & 23. & 1. & 21. & 1 & 2.3 & 0.7 & 1 & 2 & 71 & 28. & 1 & 11. & 1 & 2.3 & 0.7 & & & & & & & & & \\
\hline $\mathbf{M}$ & Jawai Selatan & 2 & 2 & 95 & 22. & 0 & 12. & 1 & 1 & 0.5 & 0 & 2 & 73 & 27. & 0 & 6. & 1 & 1 & 0.5 & 1 & 1 & 30 & 43. & 46. & 37. & 0 & 2 & 1 \\
\hline $\mathbf{N}$ & $\begin{array}{l}\text { Teluk } \\
\text { Keramat }\end{array}$ & 5 & 5 & 61 & 34. & 33. & 63. & 2 & 3.8 & 0.7 & 3 & 4 & 41 & 48. & 36. & 63. & 2 & 5 & 0.7 & 1 & 0 & 38 & 34. & 0 & 30. & 0 & 1 & 1 \\
\hline $\mathbf{O}$ & Galing & 4 & 4 & 64 & 32. & 14. & 57. & 2 & 2.5 & 0.3 & 2 & 2 & 46 & 43. & 0. & 50. & 2 & 1.5 & 0.3 & & & & & & & & & \\
\hline $\mathbf{P}$ & Tangaran & 3 & 3 & 75 & 28. & 5. & 39. & 0.8 & 2.3 & 0.7 & 3 & 0 & 56 & 35. & 5. & 23. & 0.4 & 2.3 & 0.7 & & & & & & & & & \\
\hline $\mathbf{Q}$ & Sejangkung & 2 & 2 & 74 & 28. & 0 & 18. & 1 & 1 & 0.5 & 0 & 3 & 47 & 42. & 0 & 41. & 0.6 & 1 & 0.3 & 1 & 0 & 42 & 30. & 0 & 29. & 0 & 1 & 1 \\
\hline $\mathbf{R}$ & $\begin{array}{l}\text { Sajingan } \\
\text { Besar }\end{array}$ & 3 & 3 & 79 & 26. & 2. & 39. & 1 & 1.6 & 0.5 & 0 & 4 & 46 & 43. & 3. & 48. & 1.7 & 2 & 0.5 & 1 & 0 & 42 & 30. & 0 & 29. & 0 & 1 & 1 \\
\hline $\mathbf{S}$ & Paloh & 5 & 5 & 74 & 28. & 8. & 61. & 2 & 3.4 & 0.6 & 2 & 1 & 57 & 35. & 0. & 30. & 2 & 1.6 & 0.5 & 1 & 0 & 56 & 23. & 0 & 3. & 0 & 1 & 1 \\
\hline
\end{tabular}

Note: (1) OutDegree; (2) InDegree; (3) Farness; (4) Closeness; (5) Betweenness; (6) Eigenvector; (7) Level of hierarchy in clique; (8) Effective; (9): Efficient

\begin{tabular}{|c|c|c|c|c|c|c|c|c|c|c|c|c|c|c|c|c|c|c|c|c|c|c|c|c|c|c|c|c|}
\hline \multirow{2}{*}{ CODE } & \multirow{2}{*}{ DISTRICT } & \multicolumn{9}{|c|}{ Airport } & \multicolumn{9}{|c|}{ Railway } & \multicolumn{9}{|c|}{ Water Supply } \\
\hline & & 1 & 2 & 3 & 4 & 5 & 6 & 7 & 8 & 9 & 1 & 2 & 3 & 4 & 5 & 6 & 7 & 8 & 9 & 1 & 2 & 3 & 4 & 5 & 6 & 7 & 8 & 9 \\
\hline $\mathbf{A}$ & Selakau & & & & & & & & & & & & & & & & & & & 0 & 0 & - & - & 0 & 0 & 0 & 0 & 0 \\
\hline B & Selakau Timur & & & & & & & & & & & & & & & & & & & & & & & & & & & \\
\hline $\mathbf{C}$ & Pemangkat & & & & & & & & & & & & & & & & & & & 0 & 1 & 21 & 23. & 0 & 70 & 0 & 1 & 1 \\
\hline
\end{tabular}




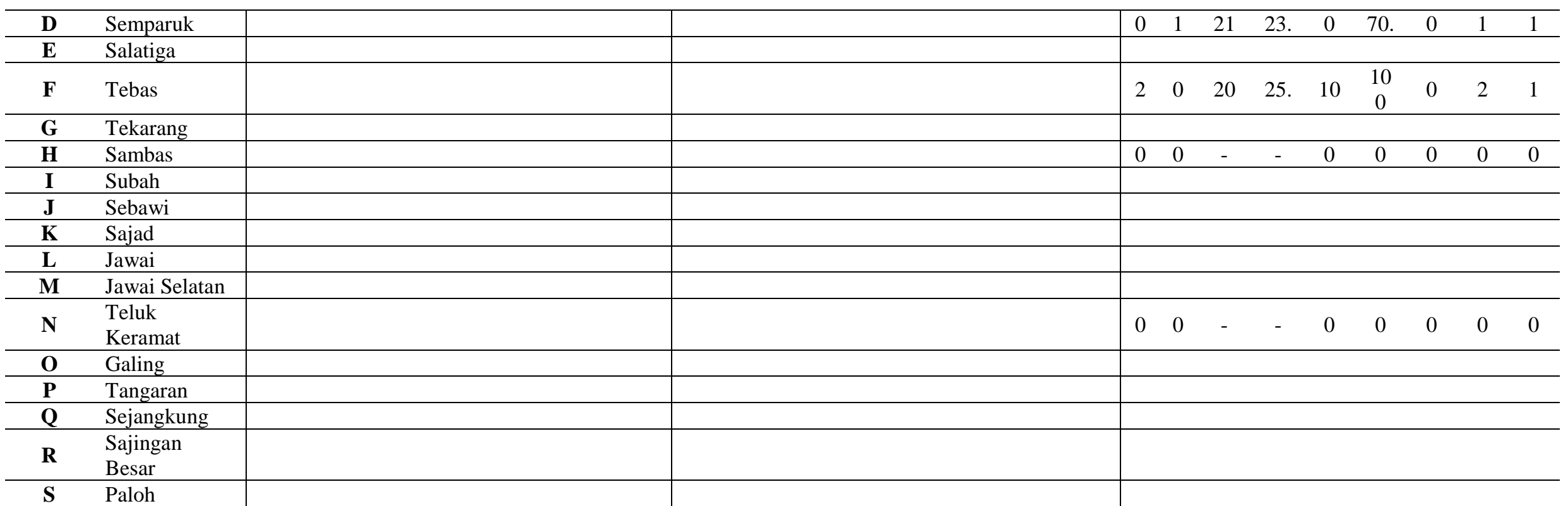

Note: (1) OutDegree; (2) InDegree; (3) Farness; (4) Closeness; (5) Betweenness; (6) Eigenvector; (7) Level of hierarchy in clique; (8) Effective; (9): Efficient

\begin{tabular}{|c|c|c|c|c|c|c|c|c|c|c|c|c|c|c|c|c|c|c|c|c|c|c|c|c|c|c|c|c|}
\hline \multirow{2}{*}{ CODE } & \multirow{2}{*}{ DISTRICT } & \multicolumn{9}{|c|}{ Electricity } & \multicolumn{9}{|c|}{ Waste Management } & \multicolumn{9}{|c|}{ Telecommunication } \\
\hline & & 1 & 2 & 3 & 4 & 5 & 6 & 7 & 8 & 9 & 1 & 2 & 3 & 4 & 5 & 6 & 7 & 8 & 9 & 1 & 2 & 3 & 4 & 5 & 6 & 7 & 8 & 9 \\
\hline $\mathbf{A}$ & Selakau & 0 & 1 & 67 & 34. & 0 & 17. & 0 & 1 & 1 & 1 & 0 & 43 & 18. & 0 & 50 & 0 & 1 & 1 & 0 & 1 & 63 & 33. & 0 & 13. & 0 & 1 & 0 \\
\hline B & Selakau Timur & 0 & 1 & 67 & 34. & 0 & 17. & 0 & 1 & 1 & & & & & & & & & & 0 & 1 & 63 & 33. & 0 & 13. & 0 & 1 & 0 \\
\hline $\mathbf{C}$ & Pemangkat & 7 & 1 & 45 & 51. & 61 & 63. & 1 & 7.7 & 0.9 & 1 & 0 & 43 & 18. & 0 & 50. & 0 & 1 & 1 & 7 & 1 & 43 & 48. & 50 & 49. & 1 & 0. & 0. \\
\hline D & Semparuk & 0 & 1 & 67 & 34. & 0 & 17. & 0 & 1 & 1 & 1 & 0 & 43 & 18. & 0 & 50 & 0 & 1 & 1 & 0 & 1 & 63 & 33. & 0 & 13. & 0 & 1 & 0 \\
\hline $\mathbf{E}$ & Salatiga & 0 & 1 & 67 & 34. & 0 & 17. & 0 & 1 & 1 & 0 & 4 & 40 & 20. & 21 & $\begin{array}{c}10 \\
0\end{array}$ & 0 & 4 & 1 & 0 & 1 & 63 & 33. & 0 & 13. & 0 & 1 & 0 \\
\hline $\mathbf{F}$ & Tebas & 0 & 1 & 67 & 34. & 0 & 17. & 0 & 1 & 1 & 1 & 0 & 43 & 18. & 0 & 50 & 0 & 1 & 1 & 2 & 2 & 38 & 55. & 26. & 52. & 2 & 0. & 0 . \\
\hline $\mathbf{G}$ & Tekarang & 0 & 1 & 64 & 35. & 0 & 22. & 0 & 1 & 1 & & & & & & & & & & 0 & 1 & 58 & 36. & 0 & 13. & 0 & 1 & 0 \\
\hline $\mathbf{H}$ & Sambas & 9 & 1 & 42 & 54. & 74. & 83. & 1 & 9.8 & 0.9 & 0 & 0 & - & - & 0 & 0 & 0 & 0 & 0 & 9 & 2 & 37 & 56. & 68. & 78. & 0.7 & 0. & 0 . \\
\hline I & Subah & 0 & 1 & 64 & 35. & 0 & 22. & 0 & 1 & 1 & & & & & & & & & & 0 & 1 & 57 & 36. & 0 & 20. & 0 & 1 & 0 \\
\hline $\mathbf{J}$ & Sebawi & 0 & 2 & 54 & 42. & 0 & 40. & 1 & 1 & 0.5 & & & & & & & & & & 0 & 1 & 57 & 36. & 0 & 20. & 0 & 1 & 0 \\
\hline
\end{tabular}




\begin{tabular}{|c|c|c|c|c|c|c|c|c|c|c|c|c|c|c|c|c|c|c|c|c|c|c|c|c|c|c|c|c|}
\hline $\mathbf{K}$ & Sajad & 0 & 1 & 64 & 35. & 0 & 22. & 0 & 1 & 1 & & & & & & & & & & 0 & 1 & 57 & 36. & 0 & 20. & 0 & 1 & 0 \\
\hline $\mathbf{L}$ & Jawai & 0 & 1 & 64 & 35. & 0 & 22. & 0 & 1 & 1 & 1 & 0 & 64 & 12. & 0 & 0 & 0 & 1 & 1 & 0 & 1 & 63 & 33. & 0 & 13. & 0 & 1 & 0 \\
\hline $\mathbf{M}$ & Jawai Selatan & 0 & 1 & 64 & 35. & 0 & 22. & 0 & 1 & 1 & 0 & 1 & 64 & 12. & 0 & 0 & 0 & 1 & 1 & 0 & 1 & 63 & 33. & 0 & 13. & 0 & 1 & 0 \\
\hline $\mathbf{N}$ & $\begin{array}{l}\text { Teluk } \\
\text { Keramat }\end{array}$ & 3 & 1 & 58 & 39. & 20. & 32. & 0 & 4 & 1 & 0 & 0 & - & - & 0 & 0 & 0 & 0 & 0 & 0 & 1 & 57 & 36. & 0 & 20. & 0 & 1 & 0 \\
\hline $\mathbf{O}$ & Galing & 0 & 2 & 78 & 29. & 0. & 16. & 0 & 2 & 1 & & & & & & & & & & 0 & 1 & 57 & 36. & 0 & 20. & 0 & 1 & 0 \\
\hline $\mathbf{P}$ & Tangaran & 0 & 1 & 80 & 28. & 0 & 8. & 0 & 1 & 1 & & & & & & & & & & 0 & 1 & 57 & 36. & 0 & 20. & 0 & 1 & 0 \\
\hline $\mathbf{Q}$ & Sejangkung & 1 & 1 & 62 & 37. & 3. & 27. & 0 & 2 & 1 & & & & & & & & & & 0 & 1 & 57 & 36. & 0 & 20. & 0 & 1 & 0 \\
\hline $\mathbf{R}$ & $\begin{array}{l}\text { Sajingan } \\
\text { Besar }\end{array}$ & 0 & 2 & 62 & 37. & 8. & 24. & 0 & 2 & 1 & & & & & & & & & & 0 & 1 & 57 & 36. & 0 & 20. & 0 & 1 & 0 \\
\hline $\mathbf{S}$ & Paloh & 0 & 1 & 80 & 28. & 0 & 8. & 0 & 1 & 1 & & & & & & & & & & 0 & 1 & 57 & 36. & 0 & 20. & 0 & 1 & 0 \\
\hline
\end{tabular}

Note: (1) OutDegree; (2) InDegree; (3) Farness; (4) Closeness; (5) Betweenness; (6) Eigenvector; (7) Level of hierarchy in clique; (8) Effective; (9): Efficient Source: Analysis Result, 2016

\section{Table 6 - Block Measurement}

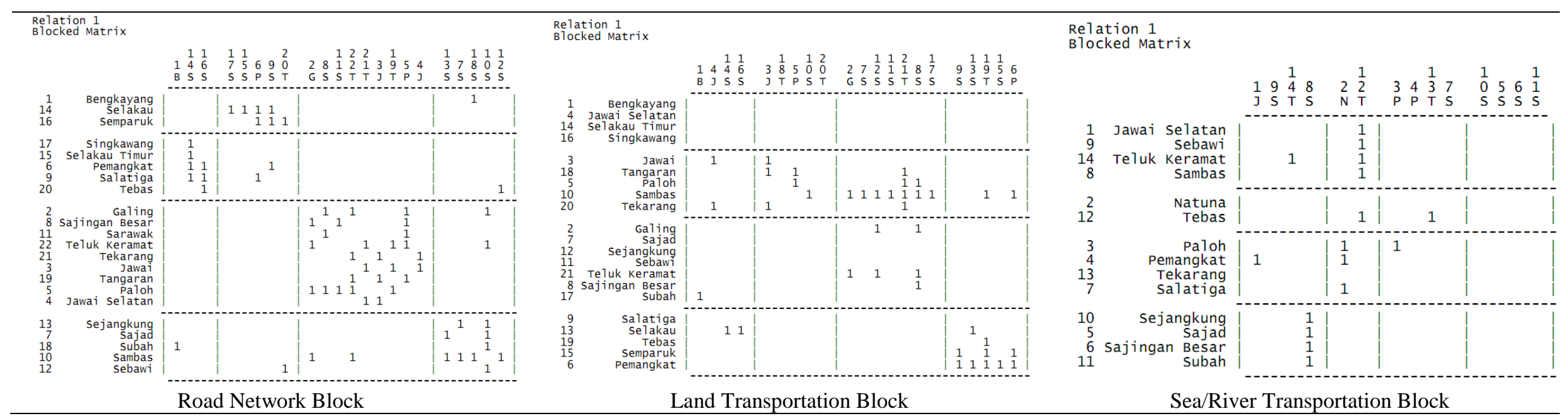




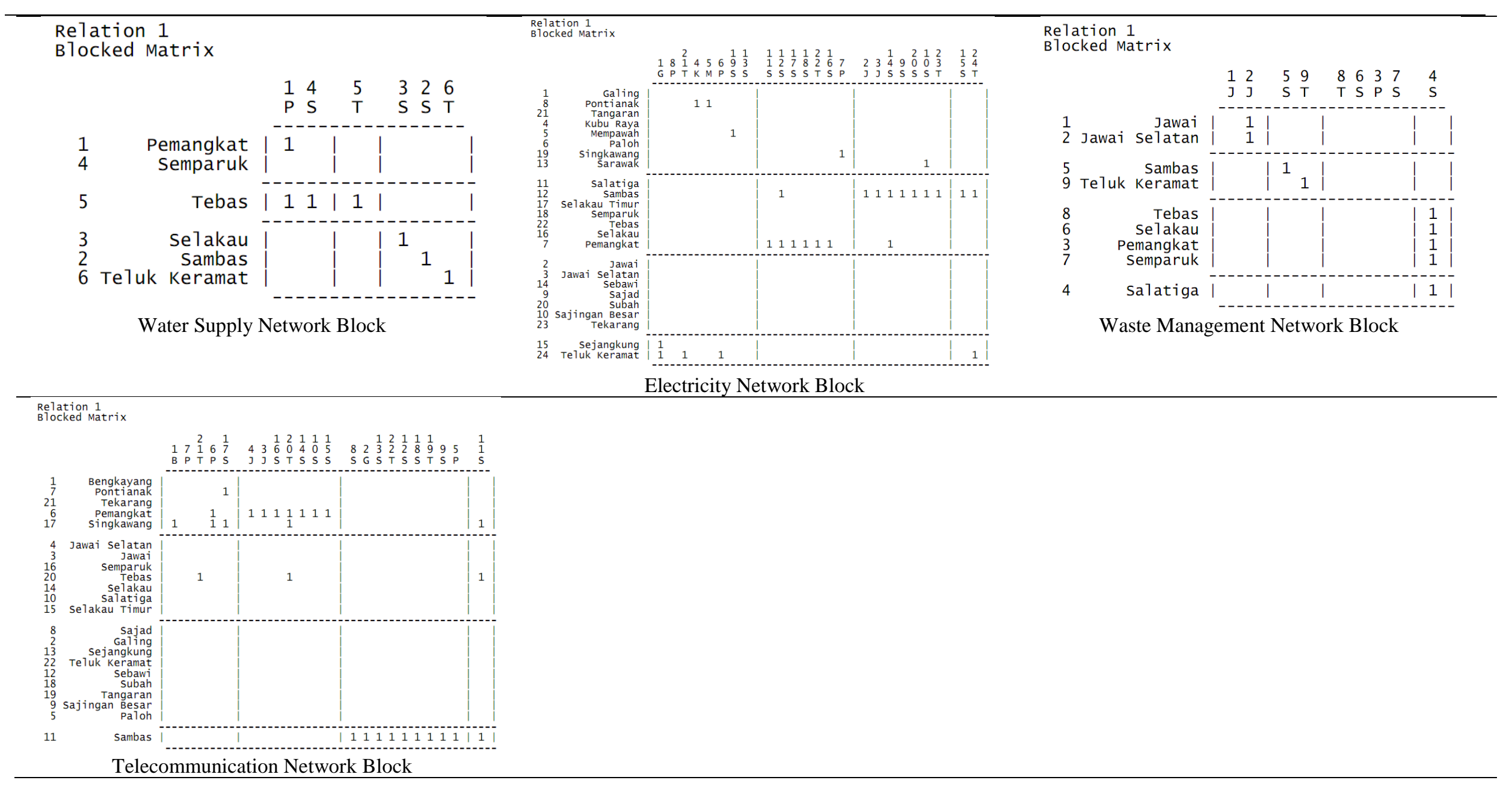


Based on the measurements above (Table 5), in general, most of the technical or infrastructure network in Sambas regency is centralized in Sambas district, as evident from the Out/InDegree measurement. This is so because of Sambas district being the capital city and the center of public service activity. Besides, Sambas district is also designated as a national (tourism) strategic area, one of whose functions is to attract visitors/tourists to come and spread to other districts. Not only Sambas district, for some networks such as water transportation, water supply, and waste, districts such as Tebas and Salatiga in the southern part of Sambas have also become the most centralized areas. As regards the most easily accessible areas, districts such as Sambas, Teluk Keramat, Sebawi, Pemangkat, Galing, and Jawai are the areas with a higher accessibility score (based on farness/closeness measurement). These districts usually become the central or the sub-main distributor for the networks in terms of the activity center, terminals, or main ports. For a maximally complete sub-graph (clique measurement), road network and public land transportation have a higher number in clique; there are $9-8$ cliques in the network. It means that those networks have a higher area interaction (connection) within the regency. With regard to block formation (Table 6), in case of main city (Sambas district) and border (Paloh district) interaction, these areas are included in the same block only in the public land transportation network. In other networks, Sambas district and Paloh district are mostly included in different blocks but they still interact with each other. As for structural holes, Sambas district overall has become the effective area in connecting to other areas. Only in some networks such as water transportation, water supply, and waste management have other areas become the effective ones.

Based on the network conditions in Sambas regency (particularly among strategic areas), it appears that the interaction between strategic areas has not assumed any appropriate direction yet. The current direction and orientation are understandable because of the concentration of activity centers in Sambas regency or West Kalimantan province,in the spatial plan. Generally, all activities related to national connectivity are centralized in Pontianak city (southern part of Sambas, as the province's capital city), such as the main port, airport, and other representative offices and services, while other regencies' capital cities serve as regional activity centers which connect areas inside the regency to the province's capital city and other regional activity centers. Due to this situation, the movement of people, goods, and services tends to be oriented to Pontianak city (southern part of Sambas regency). The border area is still considered as a "rear part" of the country; the last part of the country to be developed. Moreover, the ease of transportation flow and other supporting facilities also influence the direction of the residents in Sambas regency, which is more oriented toward the southern part, to the province's capital city.

As the capital city, Sambas district has the benefit of being an important area within the regency. According to Muazir (2018), Sambas district may become the central location of trade activities and public service, given the availability of infrastructure and facilities within the regency. This condition has helped to make Sambas district and another major city (e.g., Pontianak city) the main orientation compared to other areas/ districts. Based on economic growth theory, the causes and consequences of disparities or imbalances between areas can be assessed from the perspective of inter-regional interactions. In simple terms, areas' interactions can be understood as movements between areas at the same level of hierarchy, both horizontally and vertically (Nazara, Hewings, \& Sonis, 2006). In a general sense, interaction can be interpreted as an exchange, but it can happen without changing one for the other (Edmonds, 2007). To interact and facilitate the flow of goods and services, areas should relate with one another (connectivity). Connectivity can be interpreted as the ease of moving from one location to another for human, material, or information needs (Sokol, 2009). Connectivity can be constituted of transportation infrastructure, telecommunications, and business or business networks. Through connectivity, an area can encourage and improve connections between people, goods, and regions (Staeheli, 2012), which will also have a direct impact on the economic aspect through the inter-regional flow of business (Lobo-Guerrero, 2012). Connectivity and good access can encourage inter-regional relations that can connect producers and consumers, which in turn can increase economic growth (Vega, 2012), and certainly have an impact on the development of a region, especially lagging or border areas. From the result above, it seems there are problems with the connectivity between the study areas. This can be seen from several values or measurements of infrastructure networks, wherein there is a tendency for Sambas district and the other areas in the southern part (toward the provincial capital city), on average, to have a 
fairly large value compared to the orientation towards the northern part or the border areas (Paloh district).

\section{CONCLUSION}

As the capital city of the regency and the main tourism site, the existing infrastructure in Sambas district is certainly better than that of the other districts. Access to telecommunications, water, health, and education are available and sufficient to serve the residents in Sambas district. Most of the infrastructure network in Sambas regency is centralized in Sambas district because of the designation of Sambas district as the capital city and hub of all public service activity. Not only Sambas district, for some networks areas in the southern part of Sambas regency also have become the most centralized areas (e.g., Tebas and Pemangkat). This study has shown the characteristics of the "technical" urban network in strategic areas in Indonesia, as represented by a border area (Paloh district) and a tourism area which has also become the capital city (Sambas district). Generally speaking, due to the lack of attention to border areas, some constraints, especially in facilities and infrastructure, are still persisting and these are not distributed appropriately across the regency. Most of the infrastructure network in Sambas regency is centralized and oriented towards Sambas district, which is also the regency capital city and the tourism strategic area. Besides Sambas district, some easy access areas in line with the province's capital city have also become centralized areas. Looking at this, most of the orientation is still towards the southern part of the regency, heading to the province's capital city. Regarding the border area (Paloh), the overall linked networks are still limited due to the development priorities and the available access and the distance problem. However, seen from the "block" measurement, public land transportation has given the promise of development to both areas. It has "connected" them in one block, which means both areas have good interaction.

To improve the interaction among the strategic areas to encourage growth in the border areas and support the international gateway, the concept of "direct" connectivity or a "shortcut" with its corresponding impact (through a single node or group) would be worth considering. Besides, a multi-centered network city should work effectively and efficiently to connect areas through their roles without any administrative boundaries (Roberts, Jones, Erickson, \& Nice, 1999; Glasson \& Marshal, 2007). Improvement of the connections in the existing infrastructure can also be considered, using adaptive network criteria. This approach provides and prepares multiple choices of network configuration and prediction of their impact based on the needs and limitations. By doing this, the "predict and plan" approach for possible scenarios in the future can be successfully adopted.

\section{ACKNOWLEDGEMENT}

We thank to DIKTI and NCKU for part of financial support of the research through scholarship

\section{REFERENCES}

1 Albrechts, L., \&Mandelbaum, S. J. (Eds.). (2005). The network society, a new context for planning? New York and London:Routledge.

2 Bhaduri, S. (1992). Transport and regional development. A case study of road transport of West Bengal. New Delhi: Concept Publishing.

3 Borgatti, S., P. (1995). Centrality and AIDS. Connections, 18 (1), 112-115.

4 Borgatti, S. P., Everett, M. G., \&Freeman, L. C. (2002). UCINET for Windows: Software for social network analysis. Harvard: Analytic Technologies.

5 Borgatti, S. P., Everett, M. G., \&Johnson, J. C. (2013). Analyzing social networks. Sage Publications.

6 Burt, R. S. (1992). Structural holes, the social structure of competition. Cambridge: Harvard University Press.

7 Chow, W. S. (1988). Open policy and tourism between Guangdong and Hong Kong. Annals of Tourism Research, 15, 205218.

8 Directorate of Special and Lagging Area, National Development Planning Agency. Retrieved from http://batas.bappenas.go.id//index.php?optio $\underline{\mathrm{n}=\mathrm{com} \text { content } \& \text { task=blogsection } \& \mathrm{id}=2 \& \mathrm{It}}$ $\underline{\text { emid }=9}$

9 Edmonds, E. A. (2007). Reflections on the nature of interaction. CoDesign International Journal of CoCreation in Design and the Arts, 3(3), 139-143. 
10 Erickson, M. (2012). Network as metaphor. International Journal of Criminology and Sociological Theory, 5(2), 912-921.

11 Glasson, J., \&Marshal, T. (2007). Regional planning.London and New York:Routledge.

12 Gunn, C. A., \& Var, T. (2002). Tourism planning. Basics, concepts, cases. (4th Ed.). New York:Routledge.

13 Hanneman, R. A., \&Riddle, M. (2005). Introduction to social network methods. Riverside, CA: University of California, Riverside (published in digital form at http://faculty.ucr.edu/ hanneman/).

14 Heydebrand, W. (1999). The network metaphor as key to the analysis of complex production and service relations in a global economy. Retrieved from http://fuchsresearch.de/pdfs/ab149.pdf.

15 Indonesian Portal. (2016). Indonesian geography. Retrieved from http://indonesia.go.id/?page id=479\&lang=i $\underline{\mathrm{d}}$

16 Indonesian Telecommunication Company, Public Affairs (2014). Telecommunication Condition in Sambas Regency (interview, 2014)

17 Knoke, D., \& Yang, S. (2008). Social network analysis. Sage Publications.

18 Lobo-Guerrero, L. (2012). Connectivity as the strategization of space - the case of the Port of Hamburg. Distinktion: Scandinavian Journal of Social Theory, 13(3), 310-321.

19 Lorant, D., Geza, T., Zoltan, B., \&Bulcsu, R. (2011). The role of tourism in the development of border regions in Hungary. Romanian Journal of Economics, 2(42), 110 123.

20 Ministry of Interior. (2016). Government administration area and code. Retrieved from http://www.kemendagri.go.id/pages/datawilayah

21 Muazir, S. (2016). Applying adaptive network urbanism to improve strategic areas in Sambas Regency, West Kalimantan, Indonesia. Department of Urban Planning, NCKU, Tainan-Taiwan.
22 Muazir, S. (2018). Urban network in trade and tourism city case study: Pontianak City, Indonesia. Journalof Regional and City Planning, 29(1).

23 Muazir, S., \&Hsieh, H-C. (2013). Borderlands and tourism development in Kalimantan Island: Kalimantan Barat, Indonesia - Sarawak, Malaysia "Head to Head". Journal of Design and Built Environment, 13(1).

24 Muazir, S., \&Hsieh, H-C. (2014). Lagging yet strategic: Tourism and regional development planning in lagging-outermostforefront area (borderland) in Indonesia. Tourism: An International Interdisciplinary Journal, 63(4), 361-376.

25 National Central Statistical Agency. Retrieved from https://www.bps.go.id/index.php

26 Nazara, S., Hewings, G. J. D., \& Sonis, M. (2006). An exploratory analysis of hierarchical spatial interaction: The case of regional income shares in Indonesia. Journal of Geographical Systems, 8(3), 253-268.

27 Neuman, M. (2006). Infiltrating infrastructure: On the nature of networked infrastructure. Journal of Urban Technology, 13(1), 3-31.

28 Pavlovich, K. (2003). The evolution and transformation of a tourism destination network: The Waitomo Caves, New Zealand. Tourism Management, 24, 203-206.

29 Philllips, D. T., \& Diaz, A. G. (1981). Fundamentals of network analysis. N.J: Prentice-Hall.

30 Prokkola, E, K. (2007). Cross-border regionalization and tourism development at the Swedish-Finish border: "Destination Arctic Circle". Scandinavian Journal of Hospitality and Tourism, 7 (2), 120-138.

31 Roberts, S., Jones, T. L., Erickson, B., \&Nice, S. (1999). Place and space in the networked city: Conceptualizing the integrated metropolis. Journal of Urban Design, 4(1), 51-66.

32 Sambas Central Statistical Agency. Retrieved from http://sambaskab.bps.go.id/. 
33 Sambas Regency Government Official Website. Retrieved from http://sambas.go.id/index.php

34 Scott, J. (2013). Social network analysis (3rd Ed). Sage Publications.

35 Scott, N.,Baggio, R., \& Cooper, C. (2008). Network analysis and tourism: From theory to practice. UK, US, Canada:Channel View Publications.

36 Sokol, M. (2009). Regional connectivity. In R. Kitchin \& N. Thrift (Eds.), International encyclopedia of human geography (Vol. 9, pp. 165-180). Oxford: Elsevier.

37 Staeheli, U. (2012) Listing the global: Dis/Connectivity beyond representation? Distinktion: Scandinavian Journal of Social Theory, 13(3) 233-246.

38 Staeheli, U. (2012). Listing the global: Dis/connectivity beyond representation? Journal of Social Theory, 13(3), 233-246.

39 State Electricity Company Sub-Head. (2014). Electricity Distribution in Sambas Regency (interview).

40 Sub-Head-Department of Public Works, Sambas. (2014). Infrastructure Condition in Sambas Regency: Waste, Sanitation, Water Supply (interview)

41 Swedberg, R. (1994). Review social networks, Acta Sociologica, 37(4), 426-428.
42 The Government of Indonesia. (2007). Law No. 26 about Spatial Planning

43 The Government of Indonesia. (2008). Government Regulation No. 26 about National Spatial Plan

44 The Government of Indonesia. (2009). Law No. 10 about Tourism

45 The Government of Indonesia. (2011). Government Regulation No. 50 about National Tourism Master Plan 2010-2015.

46 The Government of Sambas Regency. (2012). Transportation, Communication and Informatics Strategic Plan

47 The Government of Sambas Regency. (2013). Draft of Sambas Spatial Plan 20122032

48 The Government of Sambas Regency. (2013). White Book of Sanitation

49 Transportation, Communication and Informatics Sub-Head. (2014). Telecommunication Condition in Sambas Regency (interview)

50 Vega, A. (2012). Accessibility and the local concentration of economic activity: A case study for county Galway. Irish Geography, 45(1), 25-44.

51 Wasserman, S., \& Faust, K. (1994). Social network analysis: Methods and applications. Cambridge University Press 